\title{
The Effects of Cigarette Advertisement and Peer Influence on Adolescent's Smoking Intention in Indonesia
}

\author{
Resti Sutrisno $^{1,2 *}$ (D) Fani Melinda ${ }^{1}$ (D) \\ ${ }^{1}$ Department of Medical Surgical Nursing, School of Nursing, Universitas Muhammadiyah Yogyakarta, Bantul, Indonesia; \\ ${ }^{2}$ Muhammadiyah Steps, Muhammadiyah Tobbaco Control Center, Universitas Muhammadiyah Yogyakarta, Bantul, Indonesia
}

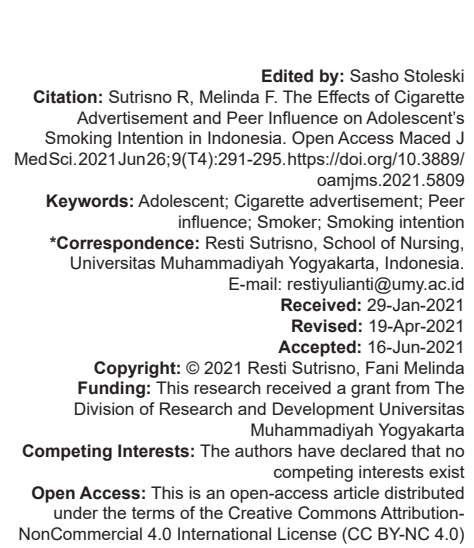

Introduction

Based on data from the World Health Organization, it was found that the number of smokers in the world aged over 15 years old reached 1.1 billion people, of which 942 million were men and 175 million were women [1]. The distribution of those numbers is as follows: 300 million people reside in developed countries, and 800 million people reside in developing countries [2]. Based on the same source, Southeast Asia (ASEAN) accounts for 122 million adult smokers, half of them living in Indonesia. The number of smokers in Indonesia reaches $65,188,338$. The data also revealed that Indonesia is also a country with the highest number of adult male smokers in ASEAN. As stated in the Tobacco Atlas, the highest prevalence of male smokers in ASEAN is in Indonesia, namely, 66\%. In terms of adult smokers, Indonesian women are in the top four among Laos, Myanmar, and the Philippines [2].

The highest percentage of Indonesian adult smokers shown below is followed by the highest proportion of children smokers in ASEAN. Based on data from the ASEAN tobacco atlas obtained in 2014, the proportion of male teenagers aged 13-15 years old who smoke reached $35.3 \%$, while the proportion of Indonesian female teenagers of the same age range who smoke was $3.4 \%$, which placed Indonesia as the $4^{\text {th }}$ highest for female adolescence smokers after the Philippines, Thailand, and Brunei Darussalam [2]. The number of child smokers is increasingly worrying by considering the number of new child smokers significantly increases every period. According to the data from Regional Health Research (RISKESDAS), the prevalence of child smokers (10-18 years old) in 2013 was at $7.2 \%$, increased to $8.8 \%$ in 2016 , and $9.1 \%$ in 2018 . It exceeds the government's target to reduce child smokers in 2019 , targeted to reach $5.4 \%$ [3], [4]. Tobacco Atlas data also states that there are 16.4 million new novice smokers aged $10-19$ years old in Indonesia annually, indicating that there are 45,000 new child smokers every day [2].

Several factors cause adolescents to become smokers, including social environment such as having smoking friends, being offered to smoke, having smoking siblings, smoking parents, consuming alcohol, the perception of smoking, exposure to cigarette advertisements, and watching television [5], [6], [7], [8]. 
The influence of cigarette advertisements as one of the reasons children are attracted to smoking are increasingly alarming. Moreover, Indonesia is ranked first in ASEAN in vulnerability to tobacco advertising and promotion exposure for youth. Indonesia has placed the first rank in "tobacco advertising or promotion seen by adolescent". Sales of cigarettes seen by adolescents in Indonesia reach $60.7 \%$, and adolescents with tobacco products reach $9 \%$ [2].

The weak control of cigarette advertisements in Indonesia makes it easier for children to be exposed to cigarette advertisements. Indonesia has no regulations covering the control of cigarette advertisements in indoor, outdoor, and Internet media. In Sleman Regency, cigarette advertisements are regulated in a radius of 500 meters from the school through a circular letter from the Sleman Regent. The proliferation of cigarette advertisements, and the vulnerability of exposure to cigarette advertisements, attracted the authors to see whether exposure to cigarette advertisements affect the intention to smoke in children in the near future and the long term.

In addition to exposure to cigarette advertisements, peers also affect a child's intention to smoke. It is as conveyed in the theory of growth and development, which states that adolescence is the age of seeking identity, so their friends will likely easily influence them. Therefore, researchers are interested in examining whether friends who smoke also affect smoking intention. Compared to other studies, this study's novelty is that this study analyzes the impact of cigarette advertisements and the exposure of peers who smoke to their current or short-term (present until a year) intention to smoke and the long-term desire (in the next 5 years) to smoke.

\section{Methods}

This study's design is a non-experimental study with a correlational design to determine the relationship between exposure to cigarette advertisements and the desire to smoke and determine the relationship between having smoking friends and the desire to smoke. The approach of this research is cross-sectional. Data collection to the respondents was only conducted once.

This study's population was adolescent students in the $1^{\text {st }}$ year at the junior high school (SMP) in three schools in Sleman Regency. We used $1^{\text {st }}$ grade because at this grade was a transition from elementary school to junior high school so adaptation with peer influence is a factor to be considered and according to the data from Regional Health Research (RISKESDAS), the prevalence of child smokers (10-18 years old) has increased. The number of samples was
318 respondents that were taken by the total sampling technique.

The variables in this study were "friends who smoke", exposure to cigarette advertisements, short-term smoking intention (currently until the next year), and long-term smoking intention (5 years). The variable of "friends who smoke" was obtained from the questionnaire, whether the respondent had close friends who smoke and how many of them smoking. The variable "exposure to cigarette advertisements" was obtained from a questionnaire consisting of nine questions divided into frequency, intensity, and duration. It was answered with a 4-scale Likert design, scaled as strongly disagree, disagree, strongly agree, and agree, and then scoring was carried out accordingly. The score range for exposure to cigarette advertisements was 9-48 divided into high categories (score 35-48), medium category (score 22-34), and low category (score 9-21). Data on the intention to smoke was also obtained from questionnaires. In terms of short-term smoking, it was from questionnaires. In terms of short-term smoking, it was obtained from the question whether the respondent wanted to smoke until a year ahead, and for long-term smoking intention, it was obtained from the question whether the respondent had the intention to smoke in the next 5 years. This questionnaire had been tested for validity and reliability and had obtained a valid and reliable result to be used as a research instrument. All instruments are valid because validity values range from 0.581 to 0.813 and $p<0.05$ for smoking intention questionnaire and 0.570-0.851 and $p<0.05$ for exposure to cigarette advertisements questionnaire. This questionnaire also reliable because a Cronbach's alpha value $>0.60 \quad(0.761$ for smoking intention questionnaire and 0.655 for exposure to cigarette advertisements questionnaire).

This research was conducted according to ethical principles. The first principle was informed consent. Before the researcher obtained any data, the researcher provided information to the respondent and the respondent's parents (because they were under $<17$ years old) and consent to participate in the parents' research. Second, each respondent and parent might choose to participate in this research or not (autonomy). The students' choice did not result in unequal treatment and brought no effect on the schooling and learning process (justice). This study's results were given to schools and the Sleman Health Office to provide benefits for controlling children's smoking phenomenon. This research had also passed an ethics review from the Health Research Ethics Committee (KEPK) Yogyakarta Aisyiyah University with ethics number 973 / KEP-UNISA/XII/2019.

The data analysis used in this research was descriptive analysis and correlation. Descriptive 
analysis was used to identify the respondent's characteristics, the description of exposure to cigarette advertisements, the description of smoking friends, short-term smoking intention (1 year ahead), and longterm smoking intention (in the next 5 years). Descriptive analysis was presented in terms of frequency and percentage. Meanwhile, correlation analysis was used to identify the relationship between "smoking friends" and cigarette advertisement exposure with the urge to smoke in the short and long term. The correlation test used was the chi-square test with a significance value if the $p<0.05$.

\section{Results}

Based on Table 1 data of the characteristics of respondents gender, it was found that most of the respondents were male, by $57.2 \%$.

Table 1: Characteristics of respondents based on gender

\begin{tabular}{lll}
\hline Variable & Frequency & Percentage \\
\hline Gender & & \\
Male & 182 & 57.2 \\
Female & 136 & 42.8 \\
Total & 318 & 100.0 \\
\hline
\end{tabular}

Based on Table 2, it was found that most of them were exposed to moderate category cigarette advertisements by 180 respondents (56.6\%) and most of them have smoker friends $(56.7 \%)$.

Table 2: Description of cigarette advertising exposure and smoking friends to respondents

\begin{tabular}{lll}
\hline Variable & Frequency & Percentage \\
\hline Cigarette advertisement exposure & & \\
Low & 113 & 35,5 \\
Moderate & 180 & 56,6 \\
High & 25 & 7,9 \\
$\quad$ Total & 318 & 100,0 \\
Smoker friend & & \\
$\quad$ There is & 182 & 57,2 \\
None & 136 & 42,8 \\
Total & 318 & 100,0 \\
\hline
\end{tabular}

Based on Table 3, it was found that there was an increase in the intention to smoke from the short term into the long term, which was $11.0 \%$ in the short term (the desire to smoke in the next 1 year) into $15.1 \%$ in the long term (the desire to smoke in the next 5 years).

Table 3: Description of intention to smoke in the short term (1 year) and long term (5 years)

\begin{tabular}{lcl}
\hline Variable & Frequency & Percentage \\
\hline Intention to smoke in the next 1 year & \\
Yes & 35 & 11.0 \\
No & 283 & 89.0 \\
Total & 318 & 100.0 \\
Intention to smoke in the next 5 years & \\
Yes & 48 & 15.1 \\
No & 270 & 84.9 \\
Total & 318 & 100.0 \\
\hline
\end{tabular}

Based on Table 4, it was found a significant relationship between having smoking friends and the desire to smoke in the short term (within the next year) with a $p<0.001$. It can also be seen that the number of respondents who had an intention to smoke in the short term and had smoking friends (10.1\%) was higher than those who did not have smoking friends $(0.9 \%)$. It is in line with the results of the correlation test of having smoking friends with long-term smoking intention (for the next 5 years), which had a significant relationship with a $p<0.001$. The long-term smoking intention was found more in respondents who had smoking friends $(12.3 \%)$ than those who did not have smoking friends (2.8\%). In this study, it was also found that the number of respondents who had smoking friends and had the intention to smoke increased from short-term into long-term desires, which was $10.1-12.3 \%$.

Table 4: Relationship of having smoking friends with short-term (next 1 year) and long-term (next 5 years) smoking intention

\begin{tabular}{llll}
\hline & \multicolumn{2}{c}{ Smoking friend } & p-value \\
\cline { 2 - 3 } & Yes & No & $<0.001$ \\
\hline Intention to smoke in the short term & $150(47.2 \%)$ & \\
Yes & $32(10.1 \%)$ & $133(41.8 \%)$ & \\
No & $3(0.9 \%)$ & 100.0 & \\
Total & 318 & & \\
Intention to smoke in the long term & $39(12.3 \%)$ & $143(45.0 \%)$ & \\
Yes & $9(2.8 \%)$ & $127(39.9 \%)$ & \\
No & 318 & 100.0 & \\
Total & & \\
\hline
\end{tabular}

Based on Table 5, it was found that there was a significant relationship between the effect of cigarette advertisements and the intention to smoke in the short term ( 1 year) with a $p<0.001$. The respondents who intended to smoke were mostly exposed to moderate cigarette advertisements $(9.1 \%)$, followed by high and finally low levels. A significant relationship was also found in the long-term (5 years) smoking intention and the exposure to cigarette advertisements with $p<0.001$. Respondents who had a long-term desire to smoke (5 years) were mostly due to moderate exposure to cigarette advertisements (10.4\%), followed by high and low exposure. In this study, it can also be seen that low, moderate, and high exposure to cigarette advertisements caused an increase in the intention to smoke in the short to long term. As stated in the data, respondents who had the desire to smoke and were exposed to cigarette advertisements increased from $9.1 \%$ (1 year) to $10.4 \%$ (5 years). Meanwhile, respondents exposed to low category cigarette advertisements also experienced an increase in the intention to smoke from 0, 3\% (1 year) to $1 \%$ (5 years). Respondents whose exposure to cigarette advertisements were in the high category also increased from $1.6 \%$ (1 year) to $3.1 \%$ (5 years).

Table 5: The relationship between cigarette advertisement exposure and the short-term (next 1 year) and long-term (next 5 years) smoking intention

\begin{tabular}{|c|c|c|c|c|c|}
\hline \multirow[t]{2}{*}{ Variable } & \multicolumn{3}{|c|}{ Cigarette advertising exposure (\%) } & \multirow[t]{2}{*}{ Total } & \multirow[t]{2}{*}{$\mathrm{p}$-value } \\
\hline & Low & Moderate & High & & \\
\hline \multicolumn{5}{|c|}{ Short-term smoking intention (1 year) } & $<0.001$ \\
\hline Yes & $1(0.3)$ & $29(9.1)$ & $5(1.6)$ & $35(11)$ & \\
\hline No & $112(35.2)$ & $151(47.5)$ & $20(6.3)$ & $283(89)$ & \\
\hline Total & $113(35.5)$ & $180(56.6)$ & $25(7.9)$ & $318(100)$ & \\
\hline \multicolumn{5}{|c|}{ Long-term desire to smoke (5 years) } & $<0.001$ \\
\hline Yes & $5(1.6)$ & $33(10.4)$ & $10(3.1)$ & $48(15.1)$ & \\
\hline No & $108(34.0)$ & $147(46.2)$ & $15(4.7)$ & $270(84.9)$ & \\
\hline Total & $113(35.6)$ & $180(56.6)$ & $25(7.8)$ & $318(100)$ & \\
\hline
\end{tabular}




\section{Discussion}

\section{The influence smoker friends on smoking intention in adolescents}

The influence of smoking friends on smoking intention in adolescents

In this study, it was found that there was a significant relationship between having smoking friends and the desire to smoke in the short term (1 year) and long term (5 years) in adolescents. This study's result is also in line with Spyratos et al. (2012) and McGee et al. (2015) revealing that there was a significant relationship between having smoking friends and the risk of smoking in adolescents with a $p<0.001$. Several studies stated that having friends who smoked increased the risk factors for smoking 28.29 times than those who did not have smoking friends [6], [9]. This result is also in line with research conducted in Korea by Chung and Joung (2014), stating that there was a significant relationship between smoking friends' influence on current smoking behavior and smoking experience [7]. Friends who smoke were a risk factor for both current smoking status and smoking experience. It is due to a permissive environment that smoking friends caused the participants to smoke as well. In addition, having friends who smoke could also increase the intention to smoke in the future, as stated by Morell et al. (2011) [10].

Several factors cause adolescents to smoke, one of which is their peers. At that age, adolescents experience forming new attitudes and interests and thinking about adjusting to their group. When a teenager has a smoking friend, he will get the pleasure of smoking by hearing and seeing it directly. This is in line with the task of adolescent social development in the early stages of adolescence, namely, early peer recognition and exploratory behavior (smoking and violence). Adolescents shift from defining themselves in relation to others to defining other people in relation to themselves as they redefine themselves [11]. The social domain, according to the TTI (theory of triadic influence), includes adolescents' immediate social surroundings, such as peer background, which contribute to the social pressure adolescents face to engage or not engage in smoking. According to the TTI, peer meaning influences adolescent smoking conduct because peers influence (a) adolescents' subjective perceptions of smoking's normativeness, (b) who motivates adolescents to conform their conduct (for example, deviant peers), and (c) the social pressures that adolescents face to smoke [12].

This study is in line with the reasons presented by Haas and David (2014) regarding why it is easier for teenagers to smoke due to peer influence, especially for adolescents. Initiation to start smoking requires information about smoking and how to smoke. This type of information is more likely to be shared by peers than information on quitting smoking. Adolescents cannot start smoking without their peers' help. Besides, the peer group of social norms that supports smoking is also needed for adolescents to start smoking [13].

\section{The effect of cigarette advertisement exposure on the intention of smoking in adolescents}

Cigarette advertisement exposure affects adolescents' desire to smoke in the short term (1 year) and long term (5 years). This statement is in line with Hanwinkell's (2011) research. In a study conducted in 2102, adolescents aged 10-12 years old who had never smoked were then exposed to six images of cigarette advertisements and then evaluated for smoking initiation within 9 months. The result was, there was an increase of initiation to smoke with exposure to cigarette advertisement (10\% increase at low exposure, $12 \%$ increase in moderate exposure, and $19 \%$ increase in high exposure to cigarette advertising). Compared to low exposure in cigarette advertisements, high exposure remained a significant predictor of adolescent initiation to start smoking [14].

Exposure to cigarette advertisements can affect adolescents' intention to smoke as what is displayed in cigarette advertisements is attractive that it is related to teenagers' lives. It corresponded with Syakur et al. (2018), which stated that cigarette advertisements always looked different and more interesting than other advertisements. It can be seen from its fashionable form, luxurious, and of course close to young people. It is undeniable that many young people want to appear like what is in cigarette advertisements. The advertising term Insightin means that an advertisement that touches consumer psychology. Upon seeing the advertisement, consumers will immediately feel associated with the subject and topic in it. Consumers will feel the same way as what is shown in advertisements. In fact, the effect is extraordinary that the advertised product image will be embedded deeply. The messages, especially the brand, conveyed by the cigarette in question, will stick in consumers' memory. The tobacco industry has carried out many studies to attract the younger generation. Based on this research on cigarette text ads, it can be seen that the cigarette industry was very fond of understanding the behavior of young people. The desire to be accepted by peers, the desire related to challenging activities, the desire to appear more mature are the most used entry points, which then was used to target young people. As a result, we saw cigarette commercials featuring jungle adventures, extreme sports bungee jumping, enthusiasts gallant mountaineers, and tough rock climbers [15]. 


\section{Conclusion}

The majority of the respondents were exposed to cigarette ads in medium category, and the majority of the respondents had smoking friends. There is an increasing percentage from short-term smoking intention (1 year) to long-term smoking intention (5 years). There was a significant relationship between exposure to cigarette advertisements and friends who smoke and the intention to smoke in the short and long-term among adolescents in Sleman Regency, Indonesia.

\section{Suggestion}

Nurses can use this study's results at public health centers (PHC) and nurses in schools to educate students about the dangers of smoking as a preventive measure to prevent smoking and facilitate smoking cessation. PHC can also work with schools to create a program of prevention of smoking and smoking cessation involving fellow peers and families (through the school committee). It will also benefit the district government as input to optimize the control of cigarette promotion and sponsorship advertisements to prevent child smoking.

\section{Acknowledgments}

This research was supported by a research grant from the Division of Research and Development Universitas Muhammadiyah Yogyakarta. Furthermore, we would like to thank the Head of the School of Nursing for their support.

\section{References}

1. Drope J, Schluger N, Cahn Z, Drope J, Hamill S, Islami F, Liber A. The Tobacco Atlas. $6^{\text {th }}$ ed. Atlanta: American Cancer Society and Vital Strategies; 2018.

2. Lian T, Dorotheo U. The Tobacco Control Atlas: ASEAN Region. $4^{\text {th }}$ ed. Bangkok, Thailand: Southeast Asia Tobacco Control Alliance; 2018.

3. Badan Penelitian dan Pengembangan Kesehatan Kementrian Kesehatan RI. Riset Kesehatan Dasar: RISKESDAS 2013. Jakarta: Kesehatan Kementrian Kesehatan RI; 2013. https:// doi.org/10.6066/jtip.2013.24.2.121
4. Badan Penelitian dan Pengembangan Kesehatan Kementrian Kesehatan RI. Hasil Utama Riset Kesehata Dasar (RISKESDAS) 2018. Jakarta: Kesehatan Kementrian Kesehatan RI; 2018. https://doi.org/10.6066/jtip.2013.24.2.121

5. Moeini B, Poorolajal J, Gharghani Z. Prevalence of cigarette smoking and associated risk factors among adolescents in Hamadan city, West of Iran in 2010. J Res Health Sci 2012;12(1):31-7.

PMid:22888712

6. Spyratos DG, Pelagidou DT, Chloros D, Haidich AB, Karetsi E, Koubaniou $\mathrm{C}$, et al. Smoking among adolescents in northern greece: A large cross-sectional study about risk and preventive factors. Subst Abuse Treat Prev Policy. 2012;7:38. https://doi. org/10.1186/1747-597x-7-38

PMid:22963755

7. Chung SS, Joung KH. Risk factors for smoking behaviors among adolescents. J Sch Nurs. 2014;30(4):262-71. PMid:24051583

8. Hanewinkel R, Isensee B, Sargent JD, Morgenstern M. Cigarette advertising and adolescent smoking. Am J Prev Med. 2010;38(4):359-66. https://doi.org/10.1016/j. amepre.2009.12.036

PMid:20307803

9. McGee CE, Trigwell J, Fairclough SJ, Murphy RC, Porcellato L, Ussher $\mathrm{M}$, et al. Influence of family and friend smoking on intentions to smoke and smoking-related attitudes and refusal self-efficacy among 9-10 year old children from deprived neighbourhoods: A cross-sectional study. BMC Public Health. 2015;15(1):225. https://doi.org/10.1186/s12889-015-1513-z PMid:25885000

10. Morrell HE, Song AV, Halpern-Felsher BL. Earlier age of smoking initiation may not predict heavier cigarette consumption in later adolescence. Prev Sci. 2011;12(3):247-54. https://doi. org/10.1007/s11121-011-0209-6

PMid:21384136

11. Christie D, Viner R. Adolescent development. BMJ. 2005;330(7486):301-4

PMid:15695279

12. Defoe IN, Dubas JS, Somerville LH, Lugtig P, van Aken MA. The unique roles of intrapersonal and social factors in adolescent smoking development. Dev Psychol. 2016;52(12):2044-56. https://doi.org/10.1037/dev0000198

PMid:27893246

13. Haas SA, Schaefer R. With a little help from my friends? Asymmetrical social influence on adolescent smoking initiation and cessation. J Health Soc Behav. 2014;55(2):126-43. https:// doi.org/10.1177/0022146514532817 PMid:24818954

14. Hanewinkel $R$, Isensee $B$, Sargent JD, Morgenstern $M$ Cigarette advertising and teen smoking initiation. Pediatrics. 2011;127(2):e271-8. https://doi.org/10.1542/peds.2010-2934 PMid:21242217

15. Syakur AA, Rusdiawan, and Sukri M. Text of cigarette advertisement: A semiology study of Roland Barthes. Int J Linguist Lit Cult. 2018;4(3):72-9. https://doi.org/10.21744/ijllc. v4n3.182 